\title{
Return Migration Schemes for International Higher Education Students. Impact for Sending and Receiving Countries
}

\author{
Luis Delgado* \\ Unit of Internationalization of Higher Education. Spanish Service for the Internationalization of Higher \\ Education. SEPIE. C/General Oraá 55, 28006 Madrid.
}

*Corresponding Author: Luis Delgado, Unit of Internationalization of Higher Education. Spanish Service for the Internationalization of Higher Education. SEPIE. C/General Oraá 55, 28006 Madrid.

\begin{abstract}
The continuous increase in the number of international students may lead to some unbalanced consequences for both sending and receiving countries. On one side, the sending countries may face brain drain losing the potential contribution from their outgoing students to their national economies while, on the other side the receiving countries may have to adapt their national higher education systems to be able to absorb an increasing number of international students with associated costs that can be recovered if the incoming students remain in the receiving country after graduation.

In addition, according to the European Agenda on Migration there is a need to increase the role of legal migration schemes in higher education in the cooperation with third countries. In fact, cooperation on legal migration with selected partner countries has been recently implemented through several pilot projects undertaken by the European Union (EU) and Member States under the EU - funded initiative Mobility Partnership Facility since 2016, with partner countries that signed a Mobility Partnership or a Common Agenda on Migration and Mobility with the EU.
\end{abstract}

This paper reviews the development of the current return migration schemes of international higher education students between developed and developing countries. The impact on both the sending and the receiving countries is considered. It is concluded that short term return migration schemes can become a possible policy option offering new legal migration channels in the frame of the cooperation of developing countries with third countries.

KEYWORDS: legal migration, international students, higher education mobility, skilled migration, mobility flows

\section{INTRODUCTION}

The incidence of migration and people's displacements in education is receiving a broad attention in the frame of the progress towards the education objectives of the Agenda 2030 for Sustainable Development (GUNI, 2019).

In particular on the Sustainable Development Goal (SDG) 4 on Education: Ensure Inclusive and Quality Education for All and Promote Lifelong Learning, there is an explicit reference (target 4.3) to higher education "to ensure equal access for all women and men to affordable and quality technical, vocational, and tertiary education, including university" (United Nations, 2015). In fact, the money spent on global scholarships, i.e. the volume of official development assistance flows for scholarships can be used to monitor SDG commitments on student mobility. In 2016 it reached 1.229 million USD (IOM, 2020).

This is coincident with an increase in the internationalization of higher education with changes in the dynamics of the mobility flows of international students. These flows are until now continuously growing and changing due to new factors in the international scenario, such as political and socioeconomic reasons, emerging nationalism and populism policies with restrictive migration measures, Brexit, America first, regional conflicts, etc. Somehow globalization seems to be now shifted to a sort of neo-nationalism with impact on the internationalization of higher education.

According to UNESCO in 2017, there were over 5.3 million international students, i.e. students who are enrolled for a tertiary degree (or higher) with a length of stay going from one year up to 7 years 
Return Migration Schemes for International Higher Education Students. Impact for Sending and Receiving Countries

outside their country of citizenship, up from 2 million in 2000 (UIS, 2019), with higher percentages at master and doctorate levels.

The numbers of internationally mobile students are increasing and destinations diversifying with the United States of America, the United Kingdom, Australia, France, Germany and the Russian Federation being the most prominent receiving countries while the most important sending countries were China, India, Germany, Republic of Korea, Nigeria, France, Saudi Arabia and several Central Asian countries. Asian students account for $53 \%$ of all students studying abroad worldwide, with an increase of other developing countries from Africa, Latin America and the Caribbean who increased by $17 \%$ in the last three years the enrolment rate in tertiary education in OECD countries.

This continuous rise of international students in the past decade was mainly driven by increasing flows to European and Asian destination countries, with a reverse effect in the United States, which however remains as the top country issuing residence permits for international tertiary-level students in the world, and Germany whose share of international students has declined.

As countries increasingly benefit from student mobility, the competition to attract and retain students has diversified the map of destinations over the past decade. New players have emerged on the international education market in the past decades, such as Australia, New Zealand, the Russian Federation, Korea, Spain, Canada and Poland. The last three mentioned countries have increased their inflow of international students, in part due to simplifications in the procedures to admit international students and qualified workers together with an increase in the number of English taught courses especially at postgraduate level (ICEF, 2018).

There is also a change in the role of traditional suppliers of international students now aspiring to attract international students with some countries setting goals to host international students such as Jordan (100.000 by 2020), Singapore (150.000 by 2025), Japan (300.000 by 2025) and China (500.000 by 2020). Therefore, the traditional South - North mobility of higher education international students is now becoming more multidirectional (R. Bhandari and R. Belyavina, 2012).

In general studies on internationally mobile students focus on the conditions (push and pull factors) that motivate students to go abroad while policymakers can be also interested because international students can become highly educated immigrants in the near future (OECD, 2013).

The main pull factors attracting international students seem to be the English language, the quality of the higher education system of the destination country as well as reputation and branding issues and the cost of higher education, while the main push factors are the unmet higher education demand in developing countries with low quality and limited access as well as political and economic reasons especially in Africa. Therefore and though the main push and pull factors remain the same, changes in the political context lead to an increasing global competition for international students.

Policies facilitating student employment after graduation can also be a driving factor. Regulations in the UK limiting the issuance of work permits caused a decline in the number of Indian students in the UK by $50 \%$ between 2011 and 2014. In the meanwhile, the number of Indian students in Australia increased by 70 per cent and in the United States by 37 per cent. Other countries like China and Germany, try to retain foreign students in their labour markets to fill local skills gaps (UNESCO, 2019).

For universities, the possibility to obtain revenues is one of the main reasons to attract international students. In 2016, international students contributed about $\$ 39.4$ billion to the United States economy. In several Asian countries, with declining birth rates and ageing populations, such as Japan, higher education is being opened to foreign students so that institutions can remain open. Mobility programs are used by some countries such as Mexico and USA as a factor in cultural diplomacy and development aid. Some sending countries, such as Brazil and Saudi Arabia, subsidize study abroad as a development strategy.

In addition, the concept of international mobility is changing from physical geographical mobility to others where the information and education are also mobile through virtual learning and the concepts of branch campuses and regional education hubs (Dubai's Knowledge Village, Qatar's Education City, Singapore's Global Schoolhouse, etc.) that become study destinations competing with the traditional ones. 
At the European level, the European Agenda on Migration (European Commission, 2015) proposed a set of measures on 4 areas including legal migration as key for delivering an effective and sustainable EU migration policy. In 2017 there were 258 million international migrants (3.4\% of the world's population), 64\% of them in high-income countries with growth from 10\% in 2000 to $14 \%$ in 2017 (UNESCO, 2019).

The Commission started in 2018 the promotion of pilot projects with third countries under the EUfunded initiative Mobility Partnership Facility (MPF) offering safe and legal alternatives of migration, enhancing legal pathways to Europe and developing strong collaboration schemes between Member States and third countries addressing two main goals of the Global Approach to Migration and Mobility: better organization of legal migration and fostering well-managed mobility and maximizing the impact of migration and mobility (European Commission, 2016).

This paper reviews the different projects and actions of return migration currently under development between receiving developed countries and third sending developing countries, paying attention to the impact on both sending and receiving countries, proposing return migration schemes of postgraduate students as a possible policy option benefiting both origin and destination countries.

\section{RETURN MIGRATION SCHEMES}

Though there is not a universally accepted definition of return migration, it is widely accepted as the act or process of going back or being taken back to the point of departure (IOM, 2019). There are two main forms of return migration: voluntary return and forced return.

While data on forced return are collected on a regular basis by national and international statistical offices and border protection and immigration agencies, data on voluntary return are more difficult to get except for those collected by the International Organization for Migration (IOM) on assisted voluntary return and reintegration programs implemented worldwide. Because of its complexity there is not an accurate global estimation of voluntary return migration, as much of it, can be initiated by the migrants themselves without implication of States or other international or national stakeholders, being therefore unrecorded.

The voluntary return can be either assisted or independent spontaneous based on the voluntary decision of the returnee without any support from national or international assistance while assisted voluntary return normally involves administrative, logistical and financial reintegration support to the migrants.

In this context cooperation on legal migration based on return migration schemes between developing and developed countries, with the final return of migrants back to their origin countries ending migration, is receiving rising recognition and being tested also for higher education international students.

This type of migration is different from other circular and repeat migration movements where the migrants may frequently and repeatedly move to foreign countries (A. F. Constant and K. F. Zimmermann, 2010). Therefore return, circular and repeat migration can be related but are not identical, since return migration is a one-time event while circular migration involves systematic and regular movements of migrants and repeat migration a repeated and frequent move to foreign countries, as schematized in Figure 1. These types of circular and repeat migration are normally used for unqualified workers such as Moroccan seasonal strawberry collectors to the south of Spain to take part in the strawberry harvest.

According to the IOM, return migration is now becoming a considerable reality not at all negligible in relation with the current outgoing permanent migration, its character is temporary rather than final as the permanent migration and it may lead to a new beginning of the migrants and its complexity and challenges are just as challenging as those of the permanent migration ones. 

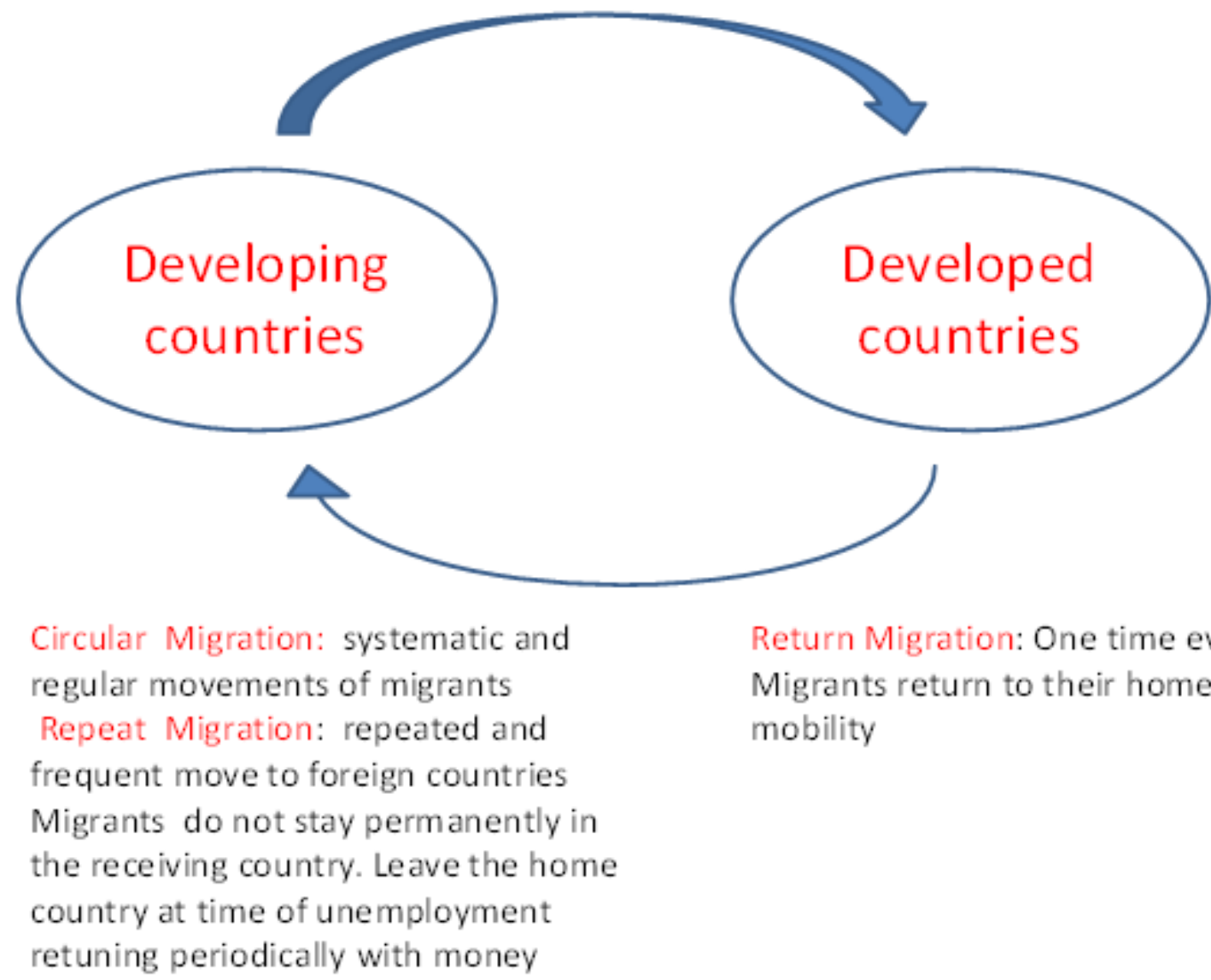

Figure1. Schemes of circular/repeat migration and return migration. Source: Own elaboration

\section{Current Return Migration Programs}

Recent trends in international migration shows that labor migration for trainees and students with high qualifications are continuously increasing (UNESCO, 2019).

For trainees the increase in 2017 was of $17 \%$ mainly due to the expansion of the Japanese Technical Intern Training Program (JITCO, 2016), This program is based in training programs conducted by overseas local companies and others in the form of employee education. The objectives of the program are to transfer skills, technologies and knowledge accumulated in Japan to developing countries with the principle that the program should not be conducted as a means of adjusting labor supply and demand.

The program is open to both individual enterprises and supervising organizations accepting employees of overseas local companies going to Japan to follow the internship in Japan enterprises and other organizations and then returning to their home country for the acquisition (1 year after entry), enhancement $\left(2^{\text {nd }}\right.$ and $3^{\text {rd }}$ year after entry $)$ or master $\left(4^{\text {th }}\right.$ and $5^{\text {th }}$ after entry) of the skills.

Another model encouraging students to return or remain in their home countries is the Sandwich Training, mainly used in the health sector to train specialized clinical doctors of developing countries (F. Kassam et al, 2009). It is an educational model in which the students complete rotations at an academic institution in the developed world as well as in their home environment. The students in developing countries take a year of postgraduate preparation at their home universities, go overseas for 1 or 1 and a half year for further course work and then return home for permanent work or $\mathrm{PhD}$ thesis.

The model allows for the building and expansion of institutional capacity at the student's home institution to create an enabling environment to practice newly acquired skills. It allows the student to focus on national priorities while gaining experience in diverse geographic and cultural contexts under the guidance of a preceptor from an institution in the developed world who teaches in both settings. Preceptors are given opportunities to continue professional growth and gain from exposure to pathology not commonly seen at home. 
Sandwich Training Programs are mainly used for qualified higher education students and professionals. They are normally offered by universities including a sandwich placement, i.e. a period of time working in an industry or studying abroad. Industrial placements are common on professionally oriented degree programs while study-abroad placements are more common on social sciences or humanities degree programs.

They are well considered by employers and students because they allow both, to gain experience in the labor world and establish contacts with the industry of interest as well as developing other transversal skills such as language capabilities, communication, team work, etc. There are also possible financial benefits with industry placements paying a salary, reduced tuition fees or grants in study-abroad placements possibly covering accommodation and daily allowances.

Depending on the duration they can be thin sandwich courses with one or two six months placements abroad during the study period or thick sandwich courses with a year-long work placement after the two first years of study returning for the final year of studies to the host university.

The International Centre for Theoretical Physics (ICTP) and the United Nations International Atomic Energy Agency (IAEA) manage the Sandwich Training Educational Program (STEP) offering PhD fellowship opportunities to $\mathrm{PhD}$ students from developing countries in physics and mathematics (ICTP/IAEA, 2019).

The objective of the program is to strengthen the scientific capability of young scientists and researchers from developing countries in order to contribute to the scientific, technological and economic development of their countries of origin. It gives access to ICTP's and IAEA's international community and to world-class training and research facilities.

$\mathrm{PhD}$ students study at their home university with financial support to visit ICTP or collaborating institutes for stays of $3-6$ months per year for up to three consecutive years. The doctoral work is made with their home advisors and co-advisors at the hosting institutes. The $\mathrm{PhD}$ is awarded by their home institutes.

Applicants have to propose a thesis project supported by an advisor of their home institution. Fellowships are then awarded on the merit of the thesis project and the STEP fellow is assigned to a host institute with a designated co-advisor. Financial support is provided either by the IAEA or ICTP in specific fields within their technical competence,

\section{Mobility Partnership Facility Pilot Projects}

In the EU and within the frame of a comprehensive migration policy, the European Commission proposed in 2017 the launching of pilot projects on legal migration in selected partner countries with the objective of facilitate and continue cooperation with third countries on the management of migratory flows. The idea was to offer additional safe and legal alternatives to students or professionals migrating for work or study purposes as well as to contribute to address labor shortages in specific sectors of the labor market of Member States (Mobility Partnership Facility, 2017).

The selection of the third countries is made on the bases of the countries signing a Mobility Partnership agreement with the EU or who have showed interest to cooperate with the EU in migration management and those with existing Common Agendas on Migration and Mobility.

The scope of the projects is based on a deep analysis of the labor market in Member States and origin countries giving preference to temporary forms of migration, including circular and repeat migration schemes of the same migrants in the case of clear linkages with seasonal peaks of work demand (such as the agriculture and tourism sectors in Spain) and also long-term migration recruitments but with special attention to possible brain drain issues.

The pilot projects may include parts of vocational or professional training and internships as well as capacity building actions in the countries of origin to ensure the maximum benefit and structures in place for its implementation.

A common structure of the pilot projects to enhance their impact has been proposed by the Commission on the first call in 2018. They should include one horizontal pillar or work-package on institutional capacity building in the country of origin, including the involvement of the private sector and public institutional structures as well as public-private partnerships to manage locally the project. 
Return Migration Schemes for International Higher Education Students. Impact for Sending and Receiving Countries

In addition three sequential work-packages on Pre-departure in the country of origin, Mobility phase in the destination country and Reintegration in the origin country following mobility, should be considered in all the pilot projects.

In the Pre-departure phase the pool of candidates from which to draw the migrants should be developed, including tailored training and orientation sessions to help the selected migrants for a better integration in the Member State destination country.

In the Mobility phase in the EU Member State, supporting measures to the migrants such as mobility support for travel and accommodation, other support on language, culture, mentoring on the study or work placements, monitoring of their academic and/or work performance as well as entrepreneurship training can normally be put in place.

In the Reintegration phase, support is provided to the entities involved in the reintegration of the migrants either to support their labor insertion or the development of entrepreneurial projects by the migrants in their communities of origin. They can include actions such as mentoring, labor recruitment, matching skills of the migrants with labor demands of local employers as well as financing of the possible start-up entrepreneurial projects developed by the returnees.

A scheme of the four main MPF pilot projects: HOMERe, Digital Explorers, PALIM and YGCA currently under development are presented in Tables 1, 2, 3 and 4 (Data Source: https://mobilitypartnershipfacility.eu/what-we-do/actions-pilot-projects).

\section{High Opportunity for Mediterranean Executive Recruitment, HOMERe}

Table1. Scheme of HOMERe MPF Pilot Project.

\begin{tabular}{|c|c|}
\hline Concept & $\begin{array}{l}\text { Internship programme based on a network of } 34 \text { academic, business and professional } \\
\text { organisations of the Mediterranean region. With a duration of } 18 \text { months, the project aims at } \\
\text { boosting the mobility of young talented students/graduates from Egypt, Morocco and Tunisia } \\
\text { by offering internship opportunities in companies based in France and operating in the target } \\
\text { countries seeking to contribute to the delivery of the European Agenda on Migration }\end{array}$ \\
\hline \multirow[t]{4}{*}{ Activities } & $\begin{array}{l}\text { Pre-Departure. Up to } 250 \text { students/graduates are be selected and matched with companies } \\
\text { based in France and operating in the target countries Egypt, Morocco and Tunisia in diverse } \\
\text { sectors such as: Information Communication and Technology (ICT), Blue Economy, } \\
\text { Tourism, Climate, Energy, Entrepreneurship and Administration. }\end{array}$ \\
\hline & $\begin{array}{l}\text { Mobility. Support candidates in the preparation of their internship and throughout their entire } \\
\text { stay by ensuring that the host company mentors each intern. The project will only consider } \\
\text { internship offers with prospects of recruitment in the partner country, for assignments of up to } \\
\text { six months, upon nomination of a local advisor and including a monthly allowance provided } \\
\text { by the company. }\end{array}$ \\
\hline & $\begin{array}{l}\text { Reintegration Implementation of } 250 \text { short-term mobility internships with companies } \\
\text { involved in transnational activities in the Mediterranean area, the project will boost } \\
\text { employability prospects of young Mediterranean graduates in the job market. HOMERe's } \\
\text { added value lies with the commitment of partner companies to consider employment } \\
\text { opportunities }\end{array}$ \\
\hline & $\begin{array}{l}\text { Network. Awareness raising activities and the set-up of new network's structures, the project } \\
\text { aim to reinforce institutional governance and increase the cooperation between academic } \\
\text { institutions and transnational private companies operating in the Mediterranean region }\end{array}$ \\
\hline Partners & University of Western Brittany. HOMERe France Association \\
\hline Countries & France, Egypt, Morocco, Tunisisa \\
\hline
\end{tabular}

\section{Digital Explorers}

Table2. Scheme of Digital Explorers MPF Pilot project

\begin{tabular}{|l|l|}
\hline Concept & $\begin{array}{l}\text { Temporary legal labour migration scheme that will bring young ICT specialists from Nigeria } \\
\text { to Lithuania. The programme is aimed at enhancing their skills and addressing labour } \\
\text { shortage gaps as well as contributing to the growth and development of career advancement } \\
\text { in both the countries. After the end of the career advancement programme reintegration } \\
\text { support will be provided to the participants to facilitate adjustment and productive use of their } \\
\text { human and social capital acquired in Lithuania. }\end{array}$ \\
\hline Activities & $\begin{array}{l}\text { Pre-Departure. Up to 50 Nigerian ICT specialists will be selected and matched with } \\
\text { employers in Lithuania. Prior to their departure, they will follow a Workplace Awareness } \\
\text { training including the development of customised professional development plans. }\end{array}$ \\
\hline
\end{tabular}


Return Migration Schemes for International Higher Education Students. Impact for Sending and Receiving Countries

\begin{tabular}{|c|c|}
\hline & $\begin{array}{l}\text { Skills Enhancement. } 3 \text { tailor-made courses targeting different profiles will be set up to } \\
\text { enhance skills and competencies of selected ICT specialists. }\end{array}$ \\
\hline & $\begin{array}{l}\text { Capacity Building. The Action will facilitate institutional learning and exchanges between } \\
\text { Nigerian and Lithuanian institutions on digital entrepreneurship and the creation of a } \\
\text { favourable environment for start-ups. }\end{array}$ \\
\hline & $\begin{array}{l}\text { Mobility. Throughout the career advancement programme (6 to } 12 \text { months), participants will } \\
\text { benefit from personalised support including logistical assistance, networking and facilitation } \\
\text { of links to the ICT ecosystem in Lithuania. }\end{array}$ \\
\hline & $\begin{array}{l}\text { Reintegration. The reintegration programme will help participants to familiarise with } \\
\text { opportunities, networks, resources and will provide trainings and career/start-up counselling } \\
\text { within the first two months of their return. }\end{array}$ \\
\hline Partners & Enterprise Lithuania. Afri / Ko. CodeAcadem. Diversity Development Group. VP Foundation \\
\hline Countries & Lithuania, Nigeria \\
\hline \multicolumn{2}{|c|}{ Pilot Project Addressing Labour Shortages through Innovative Labour Migration Models } \\
\hline \multicolumn{2}{|c|}{ Table3. Pilot Project Addressing Labour Shortages through Innovative Labour Migration Models (PALIM) } \\
\hline Concept & $\begin{array}{l}\text { The Project aims at facilitating the cooperation between Belgium and Morocco in the } \\
\text { management of regular migration, by offering a safe and lawful alternative to young } \\
\text { Moroccans willing to gain qualified work experience in Belgium. PALIM will respond to } \\
\text { labour market needs in the ICT sector Belgium and Morocco while developing professional } \\
\text { skills of young graduates in Morocco, and developing the cooperation between the two } \\
\text { countries. The Action is implemented by Enabel, the Belgian Development Agency, in } \\
\text { cooperation with employment agencies and employers' federations from both countries. }\end{array}$ \\
\hline \multirow[t]{5}{*}{ Activities } & $\begin{array}{l}\text { Technical Training Program. A technical training programme will be organised for } 80 \\
\text { young Moroccans covering technical (ICT), language and soft skills. At the end of the } \\
\text { programme, the participants will go through a selection process with Belgian and Moroccan } \\
\text { companies }\end{array}$ \\
\hline & $\begin{array}{l}\text { Pre-Departure. Selected candidates for Belgium will follow pre-departure training sessions } \\
\text { aiming at preparing candidates for their stay in Belgium with regard to legal, intercultural and } \\
\text { admin- istrative issues. }\end{array}$ \\
\hline & $\begin{array}{l}\text { Mobility. Around } 30 \text { candidates will be offered an employment con- tract in Belgium. All } \\
\text { candidates will also receive integration support, administrative and social assistance and will } \\
\text { be guided by professional and social mentors to best ensure their integration in Belgium. }\end{array}$ \\
\hline & $\begin{array}{l}\text { Reintegration. Upon return, each candidate will benefit from individual follow-up and } \\
\text { reintegration activities facilitating workers' pro- fessional reintegration in Morocco. }\end{array}$ \\
\hline & $\begin{array}{l}\text { Capacity Building. The project will develop the cooperation between the two public } \\
\text { employment organisations from Morocco and Belgium, mainly regarding international job } \\
\text { placement. }\end{array}$ \\
\hline Partners & Enabel \\
\hline Countries & Belgium. Morocco \\
\hline
\end{tabular}

\section{Young Generation as Change Agents (YGCA)}

Table4. Young Generation as Change Agents (YGCA) MPF Pilot Project

\begin{tabular}{|l|l|}
\hline Concept & $\begin{array}{l}\text { "Young Generation as Change Agents" is a one-year mobility scheme dedicated to Moroccan } \\
\text { students willing to enrol in a Master's degree in Spain. Courses offered in the context of the } \\
\text { project will address specific needs of the Moroccan labour market, with a strong focus on } \\
\text { entrepreneurship. At the end of their master's degree, the project will support graduates in } \\
\text { implementing their professional or entrepreneurial projects in Morocco. "Young Generation } \\
\text { as Change Agents" is part of the MPF Pilot Projects on Legal Migration seeking to contribute } \\
\text { to the delivery of the European Agenda on Migration. }\end{array}$ \\
\hline Activities & $\begin{array}{l}\text { Pre-Departure. Candidates will be selected based on their academic background in key } \\
\text { social and economic sectors, such as energy engineering, data sciences, cybersecurity, } \\
\text { sustainable development, biotechnology and tourism. Prior to their departure, the students } \\
\text { will follow an orientation training address- ing the political and economic context in Spain. } \\
\text { Language training and practical advice on culture, health, transportation and security will also } \\
\text { be provided in this context. }\end{array}$ \\
\hline $\begin{array}{l}\text { Mobility. total of 21 Spanish universities will host the 100 selected candidates for the } \\
\text { duration of one year. Their studies will be complemented by individual mentorship support } \\
\text { and socio-cultural activities. At the end of the academic year, the best Master's Theses and } \\
\text { proposed entrepre- neurial projects will receive a funding award to turn their project ideas }\end{array}$ \\
\hline
\end{tabular}


Return Migration Schemes for International Higher Education Students. Impact for Sending and Receiving Countries

\begin{tabular}{|l|l|}
\hline \multirow{2}{*}{} & into a reality upon returning to Morocco. \\
\cline { 2 - 2 } & $\begin{array}{l}\text { Reintegration. A reintegration programme will provide individual career and start-up } \\
\text { counselling, as well as tailored activities (workshops and training sessions) aiming at } \\
\text { informing graduates about available opportunities, resources and networks, and therefore } \\
\text { speeding up their integration into the local labour market. }\end{array}$ \\
\hline Partners & SEPIE \\
\hline Countries & Spain. Morocco \\
\hline
\end{tabular}

\section{DISCUSSION}

It is normally accepted that most migrants leave with the idea of return, but the majority remain abroad and hence the "myth of return" indicating that return never occurred. In fact, until the beginning of this XXI century, migration theories normally ignored return migration or even considered return as a failure of a successful migration (Cassarino, 2004).

However return migration is presently receiving considerable attention examining the reasons people return, the factors facilitating social and labor reinsertion, the impact in local societies and failures in the reintegration that lead migrants to migrate again (Battistella, 2018).

Impact in countries of origin and destination. Return migration can have profound consequences for countries of origin and destination as well as for the migrants themselves with impact on many socioeconomic aspects important for policy makers in both sending and receiving countries. Capacity building may also be needed both in countries of origin and destination.

Countries of origin have to deal with returning migrants perceiving their reintegration both as an opportunity and a challenge which are frequently related to lack of local capacity to reabsorb them with added value for the local economy.

Destination countries normally try to encourage the return of migrants pursuing, specially in relation with irregular flows, readmission agreements with countries of origin to ensure that they will readmit rejected or expelled migrants. They try to develop return migration schemes in order to decrease the number of irregular migrants as well as their repatriation providing incentives to return. In countries of destination the major challenges are dealing with the provision of adequate accommodation, the issuing of travel documents and visa, the implementation of voluntary return programs and the adaptation of the national legislation to the relevant international and regional standards.

Policy options. The most important policy options for sending countries are addressed towards: i) retain at home tertiary students; ii) allow or even encourage return migration and iii) engage with tertiary students abroad dealing with the diaspora of students and graduates abroad (Gribble, 2008).

Retain policies may imply considerable efforts in increasing and strengthening the higher education and research systems of the countries of origin that specially at times of crisis can simply not be affordable by the sending countries.

The alternative of promoting return migration needs to encourage migrant students to comeback home after graduation through bonding arrangements and other stipulations of the funding aid of the migrant scheme. Many developing countries are trying to encourage students to return home after graduation either permanently or with the purpose of productive collaboration and knowledge transfer to the origin countries. This can be a condition sine qua non of the public aid funding the migration mobility such as in some EU-funded projects under the MPF instrument. These bonding arrangements have been criticized because the restriction to the movement of students preventing cross-fertilization of ideas that can be useful for both the individual student and the sending country.

Engaging with the diaspora can be a very effective link to allow migrant students to contribute to the socioeconomic development of their origin countries through the settlement of scientific and technological knowledge transfer diaspora networks. Good examples can be found in China, South Korea. The diaspora networks established between migrant engineers at Silicon Valley and their origin countries in Taiwan, China and India have shown results in the development of transnational entrepreneurs contributing to the advance of science and engineering in their origin countries (Saxenian, 2005).

The reasons for return are complex and varied including both personal and structural factors in the countries of origin and destination. It can be a spontaneous choice for economic, social and/or 
personal and family-related reasons. It can also be part of labor migrations arrangements such as the end of temporary work periods abroad or, as in the case of the MPF funded projects, be part of a strategy to encourage regular and legal migration schemes.

Holistic management. In structured return migration programs there is an attempt to establish a holistic management approach including the sequential phases of Pre-Departure, Mobility, Stay and Integration in the destination country and Reintegration into the home country. The possible policies related to each phase need to be mutually comprehensive.

Cooperative approaches need to be implemented considering the different perspectives and priorities of destination countries such as the provision of legal migration schemes within their national migration systems and of the countries of origin helping them to regain skilled and talented people able to contribute to their local economies and avoiding remittances or forced return that can challenge their absorbing capacity of returnees.

In the case of voluntary return as it is intended in the EU-funded MPF initiative, there is the potential to build a convergence of interest among the three main actors, i.e. the returnees, the destination countries and the countries of origin. It can be needed to establish partnerships to facilitate effective elaboration and implementation, including bilateral inter-governments agreements and the active engagement of local communities, diaspora, businesses and the civil society at large. Cooperation is needed at bilateral or regional level for readmission, assisting with identity and travel documents and visas and building capacity in countries of origin to receive returnees.

Support to the returnees. The returnees have to be considered as potential contributors to the development of the country of origin because the acquisition of higher qualifications and skills in the case of short or medium term training return programs. They may try to reposition themselves in a new economic sector implying a change of sector normally from agriculture to industry or services or even to initiate an entrepreneurial project based on the acquired skills in the destination country.

However, it has to be considered that even if migrants have acquired innovative skills and advanced training abroad, what is not always the case, they can be underemployed in jobs below their qualification level, because the economic level of the country of origin may not allow the use of the acquired skills by migrants.

In any case there is a need to provide to the returnees specific, tailored support, orientation, information and knowledge allowing them to make informed decisions and choices. This leads to the need of providers of return advice and this role can be played either by State agencies, No Governmental Organizations (NGOs) or other International Organizations. This is especially needed if the economic situation of the origin country offers limited opportunities for employment and entrepreneurship. Therefore a readjustment process may be needed in both the countries of origin and destination to facilitate the adaptation and integration in the country of destination.

Sustainability. To ensure a sustainable return, the push factors driving migration have to be addressed, focusing on the reception and integration capacities of countries of origin and specific orientation and support to the reintegration either to reinsert migrants in the local labor market or supporting selfemployment and the launching and development of entrepreneurial projects of migrants in their communities of origin.

Specialized assistance for the socioeconomic, sanitary and cultural reintegration is needed. This may involve cash grants, educational support either for vocational training or for entrepreneurship, as well as assistance to the return communities. The type of reintegration support must be well balanced between monetary and in-kind assistance, avoiding the creation of new pull factors or incentives for irregular migration. Additional research on sustainability of returns and post-return monitoring and follow-up seems to be still needed.

Inclusivity. The return activities should be inclusive, clarifying the roles of the origin and destination countries in the management of the return and reintegration phases. In both countries inter-ministerial coordination among the different ministries with related competences, i.e. education, labor and professional insertion, diaspora, etc., is essential. Also, no public authorities, such as NGOs and other national and international organizations may play an important role, helping with return advice, dissemination of information, orienting the migrants and helping to solve incidences and special needs of vulnerable migrants. 


\section{CONCLUSION}

From the discussion above it can be said that the complexity and specificity of each situation makes that one-size-fits-all approaches are not effective. There is a need of tailoring return and reintegration programs and assistance to the specific circumstance of each country and individual migrants. However it can be concluded that return migration has the potential to bring benefits for both sending and receiving countries.

For the sending countries return migration can generate important benefits. Migrant students may acquire specialized and valuable skills and knowledge contributing to the development of the sending country after return, with the costs of this training being paid by the receiving country. In addition, students may establish significant and collaborative links with the host universities or tertiary institutions, business and industry in the receiving country, especially if internships or practical work at enterprises is included in the return migration scheme.

For the countries of origin, this type of voluntary return migration ensures the dignity and rights of the migrants as it normally includes reintegration assistance for the migrants and their communities and provides future opportunities for regular, legal migration flows.

For the destination countries this return migration is legal and more cost effective that other irregular migration flows, it can be managed with less administrative burdens and without friction with other national and international partners, opening possibilities to establish partnerships with countries of origin and other implementing partners and specialized migration agencies.

The table below summarizes the political aims, challenges and benefits that return migration may have for both origin and destination countries.

Table5. Political aims, Challenges and Potential benefits of origin and destination countries

\begin{tabular}{|c|c|c|c|}
\hline & Political aims & Challenges & Potential benefits \\
\hline $\begin{array}{l}\text { Countries of } \\
\text { origin }\end{array}$ & $\begin{array}{l}\text { Contribution of } \\
\text { returnees to the } \\
\text { local } \\
\text { socioeconomic } \\
\text { development }\end{array}$ & $\begin{array}{l}\text { - } \\
\text { Brain drain } \\
\text { contribution of their outgoing } \\
\text { students to the national economy }\end{array}$ & $\begin{array}{llr} & \text { Reduce } & \text { unmet } \\
\text { higher } & \text { education } & \text { needs } \\
\text { without extra costs } & \\
\bullet & \text { Cooperative } & \text { human } \\
\text { links with } & \text { developed } \\
\text { economies } & \\
\end{array}$ \\
\hline $\begin{array}{l}\text { Countries of } \\
\text { destination }\end{array}$ & $\begin{array}{l}\text { Decrease irregular } \\
\text { migration and } \\
\text { forced repatriation }\end{array}$ & $\begin{array}{l}\text { - Adaptation of the national } \\
\text { higher education systems to absorb } \\
\text { migrants } \\
\text { - Provision of training, } \\
\text { accommodation and other integration } \\
\text { support }\end{array}$ & $\begin{array}{l}\text { Payback of costs if } \\
\text { incoming students remain } \\
\text { contributing to the economy } \\
\text { of the receiving country } \\
\text { L Legal alternatives to } \\
\text { irregular migration }\end{array}$ \\
\hline $\begin{array}{l}\text { Origin and } \\
\text { destination } \\
\text { countries }\end{array}$ & $\begin{array}{l}\text { Joint effort } \\
\text { regulating } \\
\text { sustainable } \\
\text { migration flows }\end{array}$ & $\begin{array}{l}\text { - Holistic management } \\
\text { approach of the main sequential } \\
\text { phases: Pre-departure, Stay abroad, } \\
\text { Reintegration } \\
\text { - Bonding arrangements } \\
\text { imposing reintegration restricting } \\
\text { movements of migrants } \\
\text { - Need of tailored support and } \\
\text { assistance to migrants in each phase }\end{array}$ & $\begin{array}{l}\text { Structured legal migration } \\
\text { agreements }\end{array}$ \\
\hline
\end{tabular}

From this table it can be concluded that return migration in higher education has the potential to become a useful policy tool for both origin and destination countries contributing to develop legal migration flows in a win - win game, contributing to solve the problem of irregular migration.

Return migration, if well structured, can contribute to shift "brain drain" from origin countries into "brain gain" and "brain circulation" in line with present trends in international recruitment of students and the pursuit by international students of more global educational experiences.

Especially when combined with the diaspora option creating and/or reinforcing diaspora networks for research and knowledge transfer, return migration of skilled migrants has the potential to decisively contribute to the economic development and advance of science and technology of the origin country developing transnational networks of entrepreneurs in priority economic sectors of the countries of origin. 
Return Migration Schemes for International Higher Education Students. Impact for Sending and Receiving Countries

\section{REFERENCES}

[1] Global University Network for Innovation. Implementing the 2030 Agenda at Higher Education Institutions: Challenges and Responses. 2019.

[2] United Nations. Transforming our world: the 2030 Agenda for Sustainable Development. Resolution adopted by the General Assembly on 25 September 2015.

[3] IOM's Global Migration Data Analysis Centre (GMDAC), Migration Data Portal. 2020. Retrieved from https://migrationdataportal.org/themes/international-students

[4] UIS. UNESCO Institute for statistics. Sustainable Development Goals. Education. 2019.

[5] OECD. Education Indicators in Focus. 2013/05. July.

[6] UNESCO. INFORME DE SEGUIMIENTO DE LA EDUCACIÓN EN EL MUNDO. Migración, desplazamiento y educación: CONSTRUYENDO PUENTES, NO MUROS. 2019.

[7] ICEF Monitor. Market Intelligence for international students recruitment. Retrieved from https://monitor.icef.com/2015/11/new-oecd-report-summarises-global-mobility-trends/

[8] Rajika Bhandari and Raisa Belyavina. INTERNATIONAL HIGHER EDUCATION - NUMBER 66 WINTER 2012 Pages 14-15. Global Student Mobility: Trends and New Directions.

[9] European Commission. Brussels, 13.5.2015 COM(2015) 240 final. COMMUNICATION FROM THE COMMISSION TO THE EUROPEAN PARLIAMENT, THE COUNCIL, THE EUROPEAN ECONOMIC AND SOCIAL COMMITTEE AND THE COMMITTEE OF THE REGIONS. A EUROPEAN AGENDA ON MIGRATION

[10] European Commission. Migration and Home Affairs. 2016. Retrieved from https://ec.europa.eu/homeaffairs/what-we-do/policies/international-affairs/global-approach-to-migration/mobility-partnershipfacility_en

[11] IOM. Glossary on Migration. 2019. Retrieved from https://www.iom.int/glossary-migration-2019

[12] Amelie F. Constant and Klaus F. Zimmermann. Circular and Repeat Migration: Counts of Exits and Years Away from the Host Country. Popul Res Policy Rev (2011) 30:495-515 DOI 10.1007/s11113-010-9198-6.

[13] Japan International Trainee and Skilled Worker Cooperation Organization. Retrieved from https://www.jitco.or.jp/en/regulation/index.html

[14] Faazil Kassam, Karim F Damji, Dan Kiage, Chris Carruthers, K H Martin Kllmann. The Sandwich Fellowship: A Subspecialty Training Model for the Developing World. September 2009. Academic medicine: Journal of the Association of American Medical Colleges 84(8):1152-60.

[15] ICTP / IAEA Sandwich Training Educational Program. Retrieved from https://home.ictp.it/step/old/ictpiaea-sandwich-training-educational-programme

[16] Mobility Partnership Facility Pilot projects. Retrieved from https://mobilitypartnershipfacility.eu/what-wedo/actions-pilot-projects

[17] Cassarino, Jean-Pierre Theorising Return Migration: The Conceptual Approach to Return Migrants Revisited. January 2004. DOI: 1590/S1980-85852013000200003. Source DOAJ. License CC BY-NC 4.0.

[18] Graziano Battistella. Return Migration: A Conceptual and Policy Framework The Center for Migration Studies. Scalabrini Migration Center. 2018.

[19] Cate Gribble. Policy options for managing international student migration: The sending country's perspective. Journal of Higher Education Policy and Management, 30(1), 25-39

[20] Saxenian, A. From brain drain to brain circulation: Transnational communities and regional upgrading in India and China. Studies in Comparative International Development, 40(2), 35-61. 2005.

AUTHOR'S BIOGRAPHIES

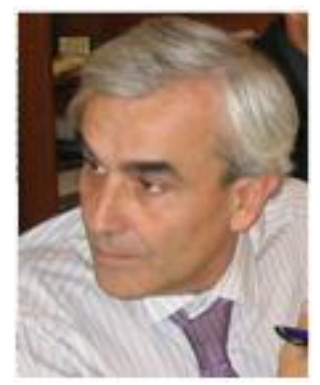

Luis Delgado, has a Ph.D. in Physics (Universidad Complutense de Madrid).

He has a long experience working for more than 30 years in Higher Education, Research and Innovation and on policy making at national and international level.

He has worked for the Spanish Ministry of Education as Deputy Director General of International Organisms and Programmes (2002 - 2007) and of Modernization and Internationalization of Universities (2009 - 2011) and as Executive Advisor at the General Secretariat of Universities $(2011-2017)$. He worked for DG Research on the Modernisation of Universities (2007-2009) at the European Commission.

Spanish Representative in international Research and Higher Education committees such as CREST, COST, BFUG, OECD, Council of Europe; European Commission, European University Institute, etc. 
Return Migration Schemes for International Higher Education Students. Impact for Sending and Receiving Countries

Author of more than 150 articles, lectures and invited presentation in Higher Education, Research and Innovation conferences. Professor in Master Programmes on these topics.

Citation: Luis Delgado. "Return Migration Schemes for International Higher Education Students. Impact for Sending and Receiving Countries" International Journal of Humanities Social Sciences and Education (IJHSSE), vol 7, no. 9, 2020, pp. 93-104. doi: https://doi.org/10.20431/2349-0381.0709009.

Copyright: () 2020 Authors. This is an open-access article distributed under the terms of the Creative Commons Attribution License, which permits unrestricted use, distribution, and reproduction in any medium, provided the original author and source are credited. 